\title{
Penile Neurofibroma
}

National Cancer Institute

\section{Source}

National Cancer Institute. Penile Neurofibroma. NCI Thesaurus. Code C162587.

A neurofibroma that occurs in the penis. 